\title{
FAKTOR-FAKTOR YANG BERHUBUNGAN DENGAN PERNIKAHAN USIA DINI DI KECAMATAN SEMIDANG ALAS MARAS KABUPATEN SELUMA
}

\section{FACTORS RELATED TO EARLY CHILDHOOD MARRIAGE IN SEMIDANG ALAS MARAS SUBDISTRICT OF SELUMA REGENCY}

\author{
Oleh: \\ Henni Febriawati ${ }^{1}$, Nopia Wati² dan Sintia Arlina ${ }^{3}$ \\ 1,2,3 Dosen dan Alumni Program Studi Kesehatan Masyarakat FIKES Universitas Muhammadiyah Bengkulu \\ Email: henni_febriawati@yahoo.com
}

\begin{abstract}
ABSTRAK
Informasi yang diperoleh dari BPS Provinsi Bengkulu (2018), Kabupaten Seluma dengan persentase tertinggi kasus pernikahan usia dini ditemukan 30,83 persen. Penyebab tingginya angka menikah usia dini adalah masalah ekonomi yang kurang, diikuti pengaruh teman sebaya, keluarga, dan hamil di luar nikah. Tujuan dari penelitian ini adalah untuk mengetahui faktor-faktor yang berhubungan dengan pernikahan usia dini di Kecamatan Semidang Alas Maras Kabupaten Seluma. Jenis penelitian ini adalah observasional analitik pada metode kuantitatif dengan pendekatan cross sectional. Penelitian ini dilakukan pada bulan Mei 2019 di Kecamatan Semidang Alas Maras Kabupaten Seluma. Populasi penelitian berjumlah 2.648 orang. Jumlah sampel penelitian sebanyak 97 orang responden laki-laki. Yang diambil dengan teknik purposive sampling. Data kemudian dianalisis menggunakan analisis univariat dan bivariat melalui uji Chi-Square. Hasil penelitian menunjukkan bahwa ada hubungan signifikan antara pendidikan $(p=0,010)$, status sosial ekonomi $(p=0,003)$, teman sebaya $(p=0,036)$ dan peran orang tua $(p=0,003)$, dengan pernikahan usia dini di Kecamatan Semidang Alas Maras Kabupaten Seluma. Tidak ada hubungan signifikan antara faktor pengetahuan, pekerjaan, dan keterpaparan media informasi dengan pernikahan usia dini di Kecamatan Semidang Alas Maras Kabupaten Seluma. Disarankan kepada dinas kesehatan untuk menjalin kerja sama dengan BKKBN untuk memberikan informasi beserta edukasi kepada remaja dan orang tua tentang dampak pernikahan usia dini.
\end{abstract}

Kata kunci : Pernikahan Usia Dini, Pendidikan, Peran Orang Tua.

\begin{abstract}
Information obtained from Central Bureau of Statistics (BPS) of Bengkulu Province (2018) indicates that Seluma District has highest percentage of cases of early marriage, 30.83 percent. Causes of the high rate of early marriage were economic problems, the influence of peers, family, and unwed pregnancy. The purpose of this study is to determine factors associated with early marriage in Semidang Alas Maras Subdistrict, Seluma Regency. The type of this research is observational analytic quantitative method with cross sectional approach. This research was conducted in May 2019 at Semidang Alas Maras Subdistrict, Seluma Regency. The study population numbered of 2,648 people. The number of research samples were 97 male respondents taken by purposive sampling technique. Data then analyzed. using univariate and bivariate analysis through the Chi-Square test. The results of the study show that there was a significant relationship between education $(p=0.010)$, socioeconomic status $(p=0.003)$, peer $(p=0,036)$ and the role of parents $(p$ $=0.003$ ), with eaarly marriage in Semidang District Alas Maras, Seluma Regency. There was no significant relationship between the factors of knowledge, employment, and exposure to information media with early marriage in Semidang Alas Maras Subdistrict, Seluma Regency. It is recommended to the health department to collaborate with National Population and Family Planning Board (BKKBN) to provide information and education to teenagers and parents about the effects of early marriage.
\end{abstract}

Keywords : Early Marriage, Education, Role of Parents. 


\section{PENDAHULUAN}

Menurut Badan Koordinasi Keluarga Berencana Nasional (BKKBN) 2012, usia pernikahan yang ideal dilakukan oleh seorang laki-laki minimal 25 tahun dan wanita 21 tahun. Namun pada kenyataanya masih begitu banyak masyarakat yang melakukan pernikahan pada usia dibawah umur 18 tahun. Indonesia adalah negara dengan presentase pernikahan usia muda tertinggi di ASEAN setelah Kamboja dan menduduki rangking ke 37 di dunia. Lebih dari 22.000 wanita berusia 10-14 tahun di Indonesia sudah menikah, dan 11,7 persen wanita usia 1519 tahun juga sudah menikah (BKKBN, 2012).

Hasil Riskesdas Provinsi Bengkulu tahun 2010 menunjukkan, usia perkawinan pertama perempuan kelompok umur 15-19 tahun di Bengkulu mencapai 45,9 persen angka ini lebih tinggi dari angka rata-rata nasional yang sebesar 41,9 persen, sedangkan usia perkawinan pertama kelompok umur 10-14 tahun di Provinsi Bengkulu termasuk tertinggi nomor 6 (enam) se Indonesia yaitu 6,5 persen (Riskesdas, 2010).

Riset Kesehatan Dasar (Riskesdas) 2013 mencatat bahwa pada wanita yang menikah umur 10-54 tahun, 2,6 persen diantaranya menikah pertama kali pada umur kurang dari 15 tahun, dan 23,9 persen menikah pada umur 15-19 tahun (Kemenkes RI, 2013).

Data Profil Kependudukan dan Pembangunan Provinsi Bengkulu tahun 2015 usia menikah pertama menunjukkan tren yang naik dari tahun 1991 sebesar 17 tahun, 1997 sebesar 18 tahun dan tahun 2012 sebesar 14,43 tahun. Rata-rata umur menikah pertama di Provinsi Bengkulu adalah 19,79 tahun masih terdapat 7 kabupaten yang berada di bawah ratarata yaitu Seluma $(18,96)$, Muko-muko $(19,06)$, Bengkulu Tengah dan Kepahiang $(19,13)$, Kaur $(19,35)$, Lebong $(19,43)$, dan Rejang Lebong $(19,56)$.

Angka pernikahan usia dini di Bengkulu sangat memprihatinkan. Badan Pusat Statistik (BPS) Provinsi Bengkulu dalam Susenas 2017 merilis data pernikahan usia dini di Provinsi Bengkulu ditemukan 16,17 persen perempuan menikah di bawah usia 16 tahun dan usia 17-18 tahun mengalami peningkatan kurun waktu 20152017 (BPS, 2017).

Berdasarkan data BPS tentang Kesejahteraan Rakyat pada tahun 2013 terdapat 10 Provinsi memiliki persentase pernikahan pada usia 10-15 tahun yaitu Kalimantan Selatan
$(15,48)$, Jawa Barat $(15,4)$, Jawa Timur $(14,92)$, Banten $(13,42)$, Jambi $(11,89)$, Sulawesi Barat $(11,66)$, Jawa Tengah $(11,57)$, Bengkulu $(10,98)$, Sulawesi Selatan $(10,95)$, dan Kalimantan Tengah $(10,22)$. Berdasarkan data tahun 2015, terdapat 20 provinsi dengan prevalensi perkawinan usia anak yang lebih tinggi dibandingkan angka nasional (22,82 persen). Provinsi Bengkulu menempati urutan ke lima belas dengan angka 24,92 persen (BPS, 2013).

Badan Pusat Statistik Provinsi Bengkulu Tahun 2018 merilis data perempuan yang menikah di usia 17-18 tahun dengan persentase tertinggi ditemukan 30,83 persen berada di Kabupaten Seluma, menyusul Kabupaten Kaur dengan persentase 27,04 persen, Kabupaten Kepahiang dengan persentase 24,54 persen, Kabupaten Muko-muko dengan persentase 24,17 persen, Kabupaten Bengkulu Utara dengan persentase 23,12 persen, Kabupaten Lebong dengan persentase 22,82 persen, Kabupaten Rejang Lebong dengan persentase 22,68 persen, Kabupaten Bengkulu Tengah dengan persentase 20,65 persen, Kabupaten Bengkulu Selatan dengan persentase 19,53 persen, dan Kota Bengkulu dengan persentase 10,38 persen (BPS Provinsi Bengkulu, 2018).

Berdasarkan sebaran wilayah, Cahaya Perempuan WCC Bengkulu mencatat tahun 2017 angka pernikahan usia dini tertinggi berada di Kabupaten Seluma. Pada range usia 16-18 tahun tercatat 40 orang. Menyusul Kabupaten Rejang Lebong 30 orang dan Kota Bengkulu 23 orang. Faktor tertinggi penyebab perkawinan usia anak adalah ekonomi 145 kasus, diikuti faktor sosial budaya 63 kasus, dan kehamilan yang tidak diinginkan 5 kasus (Cahaya Perempuan WCC Bengkulu, 2017).

Pemerintah Provinsi Bengkulu mengimplementasikan Peraturan Gubernur Nomor 33 Tahun 2018 tentang Pencegahan Perkawinan Anak. Selain Pergub, pemerintah daerah bersama dinas terkait juga membuat langkah strategis untuk memberikan pendidikan hak-hak kesehatan reproduksi dan seksual kepada anak-anak dan remaja sejak dini. Namun sampai saat ini kejadian pernikahan usia dini terus meningkat dari tahun ke tahun. Sehingga mengakibatkan persoalan Kesehatan, Angka Kematian Ibu (AKI) dan Angka Kematian Bayi (AKB).

Survei awal yang dilakukan peneliti di Badan Pemberdayaan Masyarakat Desa

44 Vol. 15, No. 1, April $2020: 1$ - .... 
Pemberdayaan Perempuan dan Keluarga Berencana di Kabupaten Seluma mencatat tahun 2018 laki-laki yang sudah menikah di Kabupaten Seluma sebanyak 33.529 orang. Pernikahan di bawah umur 25 tahun sebanyak 19.932 orang.

\section{METODE PENELITIAN}

Jenis penelitian ini adalah observasional analitik pada metode kuantitatif dengan pendekatan cross sectional. Penelitian ini dilakukan pada bulan Mei 2019 di Kecamatan Semidang Alas Maras Kabupaten Seluma. Populasi penelitian berjumlah 2.648 orang. Jumlah sampel penelitian sebanyak 97 orang responden laki-laki. Yang diambil dengan teknik purposive sampling. Data kemudian dianalisis menggunakan analisis univariat dan bivariate melalui uji Chi-Square.

\section{HASIL}

Analisis Univariat

Tabel 1. Distribusi Frekuensi Pernikahan Usia Dini di Kecamatan Semidang Alas Maras Kabupaten Seluma

\begin{tabular}{cccc}
\hline No & $\begin{array}{c}\text { Pernikahan Usia } \\
\text { Dini }\end{array}$ & Frekuensi & $\begin{array}{c}\text { Persentase } \\
(\%)\end{array}$ \\
\hline 1 & Menikah Usia Dini & 71 & 73,2 \\
\hline 2 & Normal & 26 & 26,8 \\
\hline & Jumlah & 97 & 100,0 \\
\hline
\end{tabular}

Berdasarkan tabel 1. diketahui bahwa distribusi frekuensi pernikahan usia dini di Kecamatan Semidang Alas Maras Kabupaten Seluma yang menikah usia dini sebanyak 71 orang $(73,2 \%)$ dan menikah usia normal sebanyak 26 orang $(26,8 \%)$.

Tabel 2. Distribusi Frekuensi Pendidikan di Kecamatan Semidang Alas Maras Kabupaten Seluma

\begin{tabular}{cccc}
\hline No & Pendidikan & Frekuensi & $\begin{array}{c}\text { Persentase } \\
(\%)\end{array}$ \\
\hline 1 & Rendah & 81 & 83,5 \\
\hline 2 & Tinggi & 16 & 16,5 \\
\hline & Jumlah & 97 & 100,0 \\
\hline
\end{tabular}

Berdasarkan tabel 2 diketahui bahwa distribusi frekuensi pendidikan responden di Kecamatan Semidang Alas Maras Kabupaten Seluma yang berpendidikan rendah sebanyak 81 orang $(83,5 \%)$ dan pendidikan tinggi sebanyak 16 orang $(16,5 \%)$.

Tabel 3. Distribusi Frekuensi Status Ekonomi Keluarga di Kecamatan Semidang Alas Maras Kabupaten Seluma

\begin{tabular}{cccc}
\hline No & $\begin{array}{c}\text { Status Sosial } \\
\text { Ekonomi }\end{array}$ & Frekuensi & $\begin{array}{c}\text { Persentase } \\
(\%)\end{array}$ \\
\hline 1 & Rendah & 32 & 33,0 \\
\hline 2 & Tinggi & 65 & 67,0 \\
\hline & Jumlah & 97 & 100,0 \\
\hline
\end{tabular}

Berdasarkan tabel 5 diketahui bahwa distribusi frekuensi status sosial ekonomi responden di Kecamatan Semidang Alas Maras Kabupaten Seluma yang status ekonomi keluarga rendah sebanyak 32 orang $(33,0 \%)$ dan status sosial ekonomi tinggi sebanyak 65 orang $(67,0 \%)$

Tabel 4 Distribusi Frekuensi Pengaruh Teman Sebaya di Kecamatan Semidang Alas Maras Kabupaten Seluma

\begin{tabular}{cccc}
\hline No & $\begin{array}{c}\text { Pengaruh Teman } \\
\text { Sebaya }\end{array}$ & Frekuensi & $\begin{array}{c}\text { Persentase } \\
(\%)\end{array}$ \\
\hline 1 & Ada Pengaruh & 17 & 17,5 \\
\hline 2 & $\begin{array}{c}\text { Tidak Ada } \\
\text { Pengaruh }\end{array}$ & 80 & 82,5 \\
\hline & Jumlah & 97 & 100,0 \\
\hline
\end{tabular}

Berdasarkan tabel 6 diketahui bahwa distribusi frekuensi pengaruh teman sebaya di Kecamatan Semidang Alas Maras Kabupaten Seluma yang ada pengaruh sebanyak 17 orang $(17,5 \%)$ dan tidak ada pengaruh sebanyak 80 orang $(82,5 \%)$.

Tabel 5. Distribusi Frekuensi Peran Orang Tua di Kecamatan Semidang Alas Maras Kabupaten Seluma

\begin{tabular}{cccc}
\hline No & Peran Orang Tua & Frekuensi & $\begin{array}{c}\text { Persentase } \\
(\%)\end{array}$ \\
\hline 1 & Tidak Berperan & 59 & 60,8 \\
\hline 2 & Berperan & 38 & 39,2 \\
\hline & Jumlah & 97 & 100,0 \\
\hline
\end{tabular}

Berdasarkan tabel 5 diketahui bahwa distribusi frekuensi peran orang tua di Kecamatan Semidang Alas Maras Kabupaten Seluma yang 
tidak berperan sebanyak 59 orang $(60,8 \%)$ dan berperan sebanyak 38 orang $(39,2 \%)$.

Tabel 6. Distribusi Frekuensi Keterpaparan Media Informasi di Kecamatan Semidang Alas Maras Kabupaten Seluma

\begin{tabular}{cccc}
\hline No & $\begin{array}{c}\text { Keterpaparan } \\
\text { Media Informasi }\end{array}$ & Frekuensi & $\begin{array}{c}\text { Persentase } \\
(\%)\end{array}$ \\
\hline 1 & Terpapar & 60 & 61,9 \\
\hline
\end{tabular}

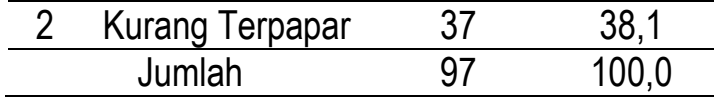

Berdasarkan tabel 6 diketahui bahwa distribusi frekuensi keterpaparan media informasi di Kecamatan Semidang Alas Maras Kabupaten Seluma yang terpapar sebanyak 60 orang $(61,9 \%)$ dan kurang terpapar sebanyak 37 orang $(38,1 \%)$.

\section{Analisis Bivariat}

Tabel 7. Hubungan Faktor Pendidikan dengan Pernikahan Usia Dini di Kecamatan Semidang Alas Maras Kabupaten Seluma

\begin{tabular}{|c|c|c|c|c|c|c|c|c|}
\hline \multirow{3}{*}{ Pendidikan } & \multicolumn{6}{|c|}{ Pernikahan Usia Dini } & \multirow{2}{*}{$\begin{array}{c}\text { P } \\
\text { value }\end{array}$} & OR \\
\cline { 2 - 8 } & $\begin{array}{c}\text { Menikah Usia } \\
\text { Dini }\end{array}$ & \multicolumn{2}{|c|}{ Normal } & \multicolumn{2}{c|}{ Total } & \\
\cline { 2 - 7 } & $\mathrm{n}$ & $\%$ & $\mathrm{n}$ & $\%$ & $\mathrm{~N}$ & $\%$ & & \\
\hline Rendah & 64 & 79,0 & 17 & 21,0 & 81 & 100 & & 4,840 \\
\hline Tinggi & 7 & 43,8 & 9 & 56,2 & 16 & 100 & 0,010 & $(1,574-$ \\
\hline Total & 71 & 73,2 & 26 & 26,8 & 97 & 100 & & $14,883)$ \\
\hline
\end{tabular}

Berdasarkan tabel 7. dapat diketahui bahwa dari 81 orang responden dengan pendidikan rendah terdapat 64 orang menikah di usia dini dan 17 orang menikah di usia normal, sedangkan dari 16 orang responden dengan pendidikan tinggi terdapat 7 orang menikah di usia dini dan 9 orang menikah di usia normal di Kecamatan Semidang Alas Maras Kabupaten Seluma.

Untuk mengetahui hubungan faktor pendidikan dengan pernikahan usia dini di Kecamatan Semidang Alas Maras Kabupaten Seluma dengan menggunakan uji Chi-Square (Fisher's Exact Test). Hasil uji Fisher's Exact Test didapat nilai Exact.sig $(p)=0,010$. Karena nilai p<0,05 maka ada hubungan yang signifikan antara faktor pendidikan dengan pernikahan usia dini di Kecamatan Semidang Alas Maras Kabupaten Seluma.

Untuk mengetahui besarnya resiko hubungan faktor pendidikan dengan pernikahan usia dini di Kecamatan Semidang Alas Maras Kabupaten Seluma dengan menggunakan nilai Odds Ratio (OR) yang didapat sebesar 4,840 artinya seorang laki-laki dengan pendidikan rendah akan beresiko melakukan pernikahan usia dini sebesar 4,480 kali lebih besar dibandingkan dengan seorang laki-laki dengan pendidikan tinggi.

Tabel 8. Hubungan Faktor Status Sosial Ekonomi dengan Pernikahan Usia Dini di Kecamatan Semidang Alas Maras Kabupaten Seluma

\begin{tabular}{|c|c|c|c|c|c|c|c|c|}
\hline \multirow{3}{*}{$\begin{array}{c}\text { Status Sosial } \\
\text { Ekonomi }\end{array}$} & \multicolumn{6}{|c|}{ Pernikahan Usia Dini } & \multirow{3}{*}{$P$ value } & \multirow{3}{*}{ OR } \\
\hline & \multicolumn{2}{|c|}{$\begin{array}{c}\text { Menikah Usia } \\
\text { Dini }\end{array}$} & \multicolumn{2}{|c|}{ Normal } & \multicolumn{2}{|c|}{ Total } & & \\
\hline & $n$ & $\%$ & $\mathrm{n}$ & $\%$ & $\mathrm{~N}$ & $\%$ & & \\
\hline Rendah & 30 & 93,8 & 2 & 6,2 & 32 & 100 & & 8,780 \\
\hline Tinggi & 41 & 63,1 & 24 & 36,9 & 65 & 100 & 0,003 & $(1,925$ \\
\hline Total & 71 & 73,2 & 26 & 26,8 & 97 & 100 & & 40,043 \\
\hline
\end{tabular}


Berdasarkan tabel 8 dapat diketahui bahwa dari 32 orang responden dengan status sosial ekonomi rendah terdapat 30 orang menikah di usia dini dan 2 orang menikah di usia normal, sedangkan dari 65 orang responden dengan status sosial ekonomi tinggiterdapat 41 orang menikah di usia dini dan 24 orang menikah di usia normal di Kecamatan Semidang Alas Maras Kabupaten Seluma.

Untuk mengetahui hubungan faktor status sosial ekonomi dengan pernikahan usia dini di Kecamatan Semidang Alas Maras Kabupaten Seluma dengan menggunakan uji Chi-Square (Continuity Correction). Hasil uji Continuity Correction didapat sebesar 8,779 dengan nilai Asymp.sig $(p)=0,003$. Karena nilai $p<0,05$ maka ada hubungan yang signifikan antara faktor status sosial ekonomi dengan pernikahan usia dini di Kecamatan Semidang Alas Maras Kabupaten Seluma.

Untuk mengetahui besarnya resiko hubungan faktor status sosial ekonomi dengan pernikahan usia dini di Kecamatan Semidang Alas Maras Kabupaten Seluma dengan menggunakan nilai Odds Ratio (OR) yang didapat sebesar 8,780 artinya seorang laki-laki dengan status sosial ekonomi rendah akan beresiko melakukan pernikahan usia dini sebesar 8,780 kali lebih besar dibandingkan dengan seorang laki-laki dengan status sosial ekonomi tinggi.

Tabel 9. Hubungan Faktor Pengaruh Teman Sebaya dengan Pernikahan Usia Dini di Kecamatan Semidang Alas Maras Kabupaten Seluma

\begin{tabular}{|l|c|c|c|c|c|c|c|c|}
\hline \multirow{4}{*}{$\begin{array}{l}\text { Pengaruh } \\
\text { Teman Sebaya }\end{array}$} & \multicolumn{6}{|c|}{\begin{tabular}{c} 
Pernikahan Usia Dini \\
\cline { 2 - 7 }
\end{tabular}} & $\begin{array}{c}\text { Menikah Usia } \\
\text { Dini }\end{array}$ & \multicolumn{2}{|c|}{ Normal } & \multicolumn{2}{|c|}{ Total } & \multirow{2}{*}{ P value } & OR \\
\cline { 2 - 7 } & $\mathrm{N}$ & $\%$ & $\mathrm{n}$ & $\%$ & $\mathrm{~N}$ & $\%$ & & \\
\hline Ada Pengaruh & 16 & 94,1 & 1 & 5,9 & 17 & 100 & & $\begin{array}{c}7,273 \\
(0,913- \\
57,916)\end{array}$ \\
\hline $\begin{array}{l}\text { Tidak Ada } \\
\text { Pengaruh }\end{array}$ & 55 & 68,8 & 25 & 31,2 & 80 & 100 & 0,036 \\
\hline Total & 71 & 73,2 & 26 & 26,8 & 97 & 100 & & \\
\hline
\end{tabular}

Berdasarkan tabel 9 dapat diketahui bahwa dari 17 orang responden yang mendapat pengaruh teman sebaya terdapat 16 orang menikah di usia dini dan 1 orang menikah di usia normal, sedangkan dari 80orang responden yang tidak mendapatkan pengaruh teman sebaya terdapat 55 orang menikah di usia dini dan 25 orang menikah di usia normal di Kecamatan Semidang Alas Maras Kabupaten Seluma.

Untuk mengetahui hubungan faktor pengaruh teman sebaya dengan pernikahan usia dini di Kecamatan Semidang Alas Maras Kabupaten Seluma dengan menggunakan uji Chi-Square (Fisher's Exact Test). Hasil uji Fisher's Exact Test didapat nilai Exact.sig $(p)=0,036$. Karena nilai $p<0,05$ maka ada hubungan yang signifikan antara faktor pengaruh teman sebaya dengan pernikahan usia dini di Kecamatan Semidang Alas Maras Kabupaten Seluma.

Untuk mengetahui besarnya resiko hubungan faktor pengaruh teman sebaya dengan pernikahan usia dini di Kecamatan Semidang Alas Maras Kabupaten Seluma dengan menggunakan nilai Odds Ratio (OR) yang didapat sebesar 7,273 artinya seorang laki-laki yang mendapatkan pengaruh dari teman sebaya akan beresiko melakukan pernikahan usia dini sebesar 7,273 kali lebih besar dibandingkan dengan seorang laki-laki yang tidak mendapatkan pengaruh dari teman sebaya. 
Tabel 10. Hubungan Faktor Peran Orang Tua dengan Pernikahan Usia Dini di Kecamatan Semidang Alas Maras Kabupaten Seluma

\begin{tabular}{|c|c|c|c|c|c|c|c|c|}
\hline \multirow{3}{*}{$\begin{array}{c}\text { Peran } \\
\text { Orang Tua }\end{array}$} & \multicolumn{6}{|c|}{ Pernikahan Usia Dini } & \multirow{3}{*}{$P$ value } & \multirow{3}{*}{ OR } \\
\hline & \multicolumn{2}{|c|}{$\begin{array}{c}\text { Menikah Usia } \\
\text { Dini }\end{array}$} & \multicolumn{2}{|c|}{ Normal } & \multicolumn{2}{|c|}{ Total } & & \\
\hline & $n$ & $\%$ & $n$ & $\%$ & $\mathrm{~N}$ & $\%$ & & \\
\hline $\begin{array}{c}\text { Tidak } \\
\text { Berperan }\end{array}$ & 50 & 84,7 & 9 & 15,3 & 59 & 100 & 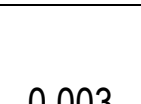 & $\begin{array}{r}4,49 \\
(1,73\end{array}$ \\
\hline Berperan & 21 & 55,3 & 17 & 44,7 & 38 & 100 & 3 & 11,69 \\
\hline Total & 71 & 73,2 & 26 & 26,8 & 97 & 100 & & \\
\hline
\end{tabular}

Berdasarkan tabel 10. dapat diketahui bahwa dari 59 orang responden yang tidak mendapatkan peran orang tuaterdapat 50 orang menikah di usia dini dan 9 orang menikah di usia normal, sedangkan dari 38 orang responden yang mendapatkan peran orang tuaterdapat 21 orang menikah di usia dini dan 17 orang menikah di usia normal di Kecamatan Semidang Alas Maras Kabupaten Seluma.

Untuk mengetahui hubungan faktor peran orang tua dengan pernikahan usia dini di Kecamatan Semidang Alas Maras Kabupaten Seluma dengan menggunakan uji Chi-Square (Continuity Correction). Hasil uji Continuity Correction didapat sebesar 8,793 dengan nilai
Asymp.sig $(p)=0,003$. Karena nilai $p<0,05$ maka ada hubungan yang signifikan antara faktor peran orang tua dengan pernikahan usia dini di Kecamatan Semidang Alas Maras Kabupaten Seluma.

Untuk mengetahui besarnya resiko hubungan faktor peran orang tua dengan pernikahan usia dini di Kecamatan Semidang Alas Maras Kabupaten Seluma dengan menggunakan nilai Odds Ratio (OR) yang didapat sebesar 4,497 artinya seorang laki-laki yang tidak mendapatkan peran orang tua akan beresiko melakukan pernikahan usia dini sebesar 4,497 kali lebih besar dibandingkan dengan seorang laki-laki yang mendapatkan peran orang tua.

Tabel 11. Hubungan Faktor Keterpaparan Media Informasi dengan Pernikahan Usia Dini di Kecamatan Semidang Alas Maras Kabupaten Seluma

\begin{tabular}{|c|c|c|c|c|c|c|c|c|}
\hline \multirow{3}{*}{$\begin{array}{l}\text { Keterpaparan } \\
\text { Media Informasi }\end{array}$} & \multicolumn{6}{|c|}{ Pernikahan Usia Dini } & \multirow{3}{*}{$P$ value } & \multirow{3}{*}{ OR } \\
\hline & \multicolumn{2}{|c|}{$\begin{array}{l}\text { Menikah Usia } \\
\text { Dini }\end{array}$} & \multicolumn{2}{|c|}{ Normal } & \multicolumn{2}{|c|}{ Total } & & \\
\hline & $\mathrm{n}$ & $\%$ & $\mathrm{n}$ & $\%$ & $\mathrm{~N}$ & $\%$ & & \\
\hline Terpapar & 47 & 78,3 & 13 & 21,7 & 60 & 100 & & \\
\hline $\begin{array}{l}\text { Kurang } \\
\text { Terpapar }\end{array}$ & 24 & 64,9 & 13 & 35,1 & 37 & 100 & 0,223 & $\begin{array}{l}1,958 \\
(0,786- \\
1,878)\end{array}$ \\
\hline Total & 71 & 73,2 & 26 & 26.8 & 97 & 100 & & \\
\hline
\end{tabular}

Berdasarkan tabel 11 dapat diketahui bahwa dari 60 orang responden yang terpapar media informasi terdapat 47 orang menikah di usia dini dan 13 orang menikah di usia normal, sedangkan dari 37 orang responden yang tidak terpapar media informasi terdapat 24 orang menikah di usia dini dan 13 orang menikah di usia normal di Kecamatan Semidang Alas Maras Kabupaten Seluma.

Untuk mengetahui hubungan faktor keterpaparan media informasi dengan pernikahan usia dini di Kecamatan Semidang Alas Maras Kabupaten Seluma dengan menggunakan uji Chi-Square (Continuity Correction). Hasil uji Continuity Correction didapat sebesar 1,485 dengan nilai Asymp.sig ( $p)=0,223$. Karena nilai $p>0,05$ maka tidak ada hubungan yang signifikan antara faktor keterpaparan media informasi dengan pernikahan usia dini di Kecamatan Semidang Alas Maras Kabupaten Seluma.

Untuk mengetahui besarnya resiko hubungan faktor keterpaparan media informasi dengan pernikahan usia dini di Kecamatan 
Semidang Alas Maras Kabupaten Seluma dengan menggunakan nilai Odds Ratio (OR) yang didapat sebesar 1,958 artinya seorang lakilaki yang terpapar media informasi akan beresiko melakukan pernikahan usia dini sebesar 1,958 kali lipat dibandingkan dengan seorang laki-laki yang kurang terpapar media informasi.

\section{PEMBAHASAN}

Hubungan Faktor Pendidikan dengan Pernikahan Usia Dini di Kecamatan Semidang Alas Maras Kabupaten Seluma

Berdasarkan hasil penelitian didapatkan ada hubungan yang signifikan antara faktor pendidikan dengan pernikahan usia dini di Kecamatan Semidang Alas Maras Kabupaten Seluma dengan nilai $p(0,010)$. Hal ini menunjukkan bahwa semakin tinggi tingkat pendidikan semakin kecil kemungkinan seorang laki-laki melakukan pernikahan usia dini dan sebaliknya semakin rendah tingkat pendidikan maka semakin besar kemungkinan seorang lakilaki melakukan pernikahan usia dini.

Berdasarkan hasil dari kuesioner yang didapatkan pada saat penelitian, sebagian besar pendidikan terakhir responden yang melakukan pernikahan usia dini yaitu tidak sekolah (tidak tamat SD), SD dan SMP. Pernikahan usia dini seringkali menyebabkan anak tidak lagi bersekolah, karena mereka mempunyai tanggungjawab baru, yaitu sebagai istri dan sebagai calon ibu, atau kepala keluarga dan calon ayah, yang lebih banyak berperan mengurus rumah tangga dan anak yang akan hadir. Hal lainnya yaitu karena biaya pendidikan yang tidak terjangkau, mereka berhenti sekolah dan kemudian dinikahkan untuk mengalihkan beban tanggung jawab orang tuanya tersebut kepada pasangannya.

Hasil penelitian ini sejalan dengan penelitian yang dilakukan oleh Qibtiyah, 2014 menyebutkan responden dengan berpendidikan tingkat dasar akan menikah di usia muda 4,46 kali lebih besar jika dibandingkan dengan responden yang berpendidikan tingkat menengah ke atas yang mengatakan pendidikan remaja merupakan faktor dalam menentukan usia kawin pertama. Hasil penelitian menunjukkan bahwa mayoritas pendidikan responden masih tergolong rendah $(96,2 \%)$. Faktor biaya pendidikan yang mahal menjadi alasan responden tidak melanjutkan pendidikan. Tingkat pendidikan yang berbeda akan mempengaruhi perilaku berbeda pula dalam mengambil keputusan untuk menikah atau tidak menikah. Dari hasil wawancara yang dilakukan responden tidak mengetahui tentang dampak negatif yang bisa terjadi akibat dari pernikahan dini. Hasil penelitian ini sejalan dengan hasil penelitian Pratiwi (2017), bahwa ada hubungan antara pendidikan dengan pernikahan usia dini di Kabupaten Bengkulu Tengah dengan nilai $p(0,000)$ OR $(0,276 ; 0,224-$ $0,341)$. Dengan demikian orang yang berpendidikan rendah mempunyai peluang 0,276 kali untuk menikah dini dibandingkan dengan yang berpendidikan tinggi di Kabupaten Bengkulu Tengah.

Menurut Rafidah (2009), Semakin tinggi pendidikan seseorang, informasi yang dimiliki lebih luas dan lebih mudah diterima termasuk informasi tentang kesehatan reproduksi, usia pernikahan yang baik dan dampak apabila melakukan pernikahan usia muda. Sedangkan bila tingkat pendidikan seseorang rendah maka akan berakibat terputusnya informasi yang diperoleh pada jenjang pendidikan yang lebih selain juga meningkatkan kemungkinan aktivitas remaja yang kurang. Dalam persepsi remaja tentang pernikahan dengan pendidikan lebih tinggi akan mengurangi risiko menikah usia muda.

\section{Hubungan Faktor Status Sosial Ekonomi dengan Pernikahan Usia Dini di Kecamatan Semidang Alas Maras Kabupaten Seluma}

Berdasarkan hasil penelitian didapatkan, ada hubungan yang signifikan antara faktor status sosial ekonomi dengan pernikahan usia dini di Kecamatan Semidang Alas Maras Kabupaten Seluma dengan nilai $p(0,003)$. Hal ini menunjukkan bahwa semakin tinggi status sosial ekonomi maka semakin kecil kemungkinan seorang laki-laki melakukan pernikahan usia dini dan sebaliknya semakin rendah status sosial ekonomi maka semakin besar kemungkinan seorang laki-laki melakukan pernikahan usia dini. Hal ini dapat dilihat dari jawaban responden saat pengisian kuesioner yang menunjukkan bahwa rata-rata pendapatan responden yang melakukan pernikahan usia dini kurang dari UMR.

Hasil penelitian ini sejalan dengan penelitian yang dilakukan oleh Muzaffak (2013), bahwa pendapatan orang tua memiliki hubungan yang signifikan dengan pernikahan dini. Hal yang mempengaruhi kejadian pernikahan usia muda bukan dari sudut pandang pekerjaan remaja 
melainkan lebih ke pekerjaan orang tua. Pekerjaan orang tua mencerminkan status sosial ekonomi dari keluarga remaja tersebut. Kehidupan seseorang sangat ditunjang oleh kemampuan ekonomi keluarga, sebuah keluarga yang berada di garis kemiskinan akan mengambil keputusan bahwa untuk meringankan beban orang tuanya maka anak wanita dinikahkan dengan orang-orang yang dianggap mampu. Pekerjaan seseorang dapat mencerminkan pendapatan, status sosial, pendidikan dan masalah kesehatan bagi orang itu sendiri.

Penelitian ini tidak sejalan dengan penelitian yang dilakukan oleh Rosmawar (2013) yang menyatakan bahwa pendapatan orang tua tidak ada hubungan dengan pernikahan usia dini karena seseorang melakukan pernikahan dini dikarenakan tata cara dalam pergaulan yang mengharuskan mereka melakukan pernikahan dini. Hal ini juga didukung oleh hasil penelitian Raharjo (2013) yang menunjukkan tidak ada hubungan antara status sosial ekonomi dengan pernikahan dini. Status ekonomi erat kaitannya dengan pendapatan keluarga.

Dari hasil penelitian Pratiwi (2017), menunjukkan rendahnya perekonomian keluarga menyebabkan orang tua tidak mampu membiayai pendidikan anaknya sehingga anak menjadi putus sekolah. Usia informan yang < 18 tahun membuatnya kesulitan mencari pekerjaan, akibatnya mereka hanya berdiam diri di rumah saja tanpa memiliki kegiatan. Keputusan menikah usia anak diambil dengan alasan ingin meringankan beban orang tua, diharapkan ketika sudah menikah beban orang tua menjadi berkurang dan perekonomian keluarga dapat dibantu dari pendapatan yang dihasilkan suami.

\section{Hubungan Faktor Pengaruh Teman Sebaya dengan Pernikahan Usia Dini di Kecamatan Semidang Alas Maras Kabupaten Seluma}

Berdasarkan hasil penelitian didapatkan, ada hubungan yang signifikan antara faktor pengaruh teman sebaya dengan pernikahan usia dini di Kecamatan Semidang Alas Maras Kabupaten Seluma dengan nilai $p(0,036)$. Hal ini menunjukkan bahwa semakin tidak ada pengaruh teman sebaya maka semakin kecil kemungkinan seorang laki-laki melakukan pernikahan usia dini dan sebaliknya semakin ada pengaruh teman sebaya maka semakin besar kemungkinan seorang laki-laki melakukan pernikahan usia dini. Hal ini dapat dilihat dari jawaban responden saat pengisian kuesioner yang mengatakan bahwa responden menikah karena mendengarkan cerita seksual dari teman yang sudah menikah, menikah karena takut kehilangan pacar, menikah karena teman menikah terlihat bahagia dengan pasangan dan anak-anaknya. Selain itu, responden menikah juga karena melihat teman yang sudah menikah dan kehidupannya mapan dan terlihat semakin dewasa.

Perkembangan remaja dalam proses pendewasaan, pengaruh keluarga telah bergeser menjadi teman sebaya. Hal ini dibuktikan dengan besarnya pengaruh langsung dari teman sebaya positif terhadap perilaku berisiko. Remaja yang memutuskan melakukan pernikahan usia dini dapat termotivasi oleh pengaruh kelompok (teman sebaya) dalam upaya ingin menjadi bagian dari kelompoknya dengan mengikuti norma-norma yang dianut oleh kelompoknya.

Hasil penelitian ini sejalan dengan penelitian yang dilakukan oleh Karjono (2014) dari hasil penelitian tersebut menunjukkan hasil bahwa peran teman sebaya mempunyai pengaruh terhadap pernikahan usia dini dengan nilai $p(0,001)$. Dari hasil penelitian tersebut juga menunjukan bahwa peran teman sebaya mempunyai risiko 2,492 kali lebih besar untuk melakukan pernikahan usia dini.

Menurut Teori L. Green teman sebaya merupakan salah satu faktor pendorong yang memiliki pengaruh dalam mengatur bahkan mendorong anak remajanya melakukan pernikahan usia dini. Hal ini juga didukung oleh penelitian yang dilakukan oleh Pratiwi (2017) menyatakan bahwa ada hubungan antara teman sebaya dengan pernikahan usia dini di Kabupaten Bengkulu Tengah. Responden yang terpengaruh teman mempunyai peluang 2,024 kali untuk menikah dini dibandingkan yang tidak terpengaruh teman.

Menurut Dumilah (2019), terdapat hubungan yang bermakna antara teman sebaya dengan persepsi remaja tentang perkawinan di bawah umur dengan nilai $p(0,035)$. Responden yang memiliki teman sebaya yang tidak mendukung perkawinan dibawah umur berpeluang 2,632 kali memiliki persepsi baik dibandingkan responden yang mendukung perkawinan dibawah umur.

Hubungan Faktor Peran Orang Tua dengan Pernikahan Usia Dini di Kecamatan Semidang Alas Maras Kabupaten Seluma

50 Vol. 15, No. 1, April 2020 : 1 - 73 | 
Berdasarkan hasil penelitian didapatkan, ada hubungan yang signifikan antara faktor peran oang tua dengan pernikahan usia dini di Kecamatan Semidang Alas Maras Kabupaten Seluma dengan nilai $p(0,003)$. Hal ini menunjukkan bahwa semakin berperan orang tua maka semakin kecil kemungkinan seorang lakilaki melakukan pernikahan usia dini dan sebaliknya semakin tidak berperan orang tua maka semakin besar kemungkinan seorang lakilaki melakukan pernikahan usia dini. Hal ini dapat dilihat dari jawaban responden saat pengisian kuesioner yang mengatakan bahwa orang tua tidak meluangkan waktu untuk mendiskusikan tentang permasalahan yang dihadapi. Orang tua tidak memberikan nasehat tentang menikah usia dini. Orang tua tidak melarang untuk menikah jika belum tamat SMA. Orang tua tidak melarang untuk berpacaran dan orang tua tidak menghubungi jika terlambat pulang ke rumah. Selain itu, responden juga mengatakan bahwa menikah atas kemauannya sendiri, bukan karena didesak ataupun dijodohkan oleh orang tua.Ditambah lagi orang tua tidak pernah memberi tahu dampak dari menikah di usia dini. Oleh karena itu, perlu dilakukan penyuluhan baik bagi remaja maupun bagi orang tua tentang dampak serta cara pencegahan pernikahan usia dini sehingga orang tua bisa berperan dalam mencegah pernikahan usia dini atau paling tidak berfikir untuk menunda usia pernikahan mengingat banyaknya dampak negatif yang muncul apabila menikah di usia dini.

Hasil penelitian ini sejalan dengan penelitian yang dilakukan oleh Karjono (2014), yang menyatakan bahwa remaja yang orang tuanya berperan dalam mengambil keputusan mempunyai resiko 2,121 kali menikah pada usia dini dibanding remaja yang orang tuanya tidak berperan dalam mengambil keputusan. Hal ini juga didukung oleh penelitian yang dilakukan oleh Desiyanti (2015), bahwa terdapat hubungan antara peran orang tua dengan pernikahan dini pada anaknya dengan nilai OR $(5,781)$ artinya responden yang memiliki orang tua yang tidak berperan mempunyai peluang 5,781 kali untuk menikah usia dini dibandingkan yang ada peran orang tua.

Menurut Soetjiningsih (2006), bahwa semakin baik hubungan orang tua dengan anak remajanya maka semakin baik perilaku seksual pranikah remaja. Orang tua yang sibuk, kualitas pengasuhan yang buruk, dan perceraian orang tua, remaja dapat mengalami depresi, kebingungan, dan ketidakmantapan emosi yang menghambat untuk tanggap terhadap kebutuhan remaja sehingga remaja dapat dengan mudah terjerumus pada perilaku yang menyimpang seperti seks pranikah.

\section{Hubungan Faktor Keterpaparan Media Informasi dengan Pernikahan Usia Dini di Kecamatan Semidang Alas Maras Kabupaten Seluma}

Berdasarkan hasil penelitian didapatkan, tidak ada hubungan yang signifikan antara faktor keterpaparan media informasi dengan pernikahan usia dini di Kecamatan Semidang Alas Maras Kabupaten Seluma dengan nilai $p(0,223)$. Hal ini menunjukkan bahwa terpapar ataupun kurang terpaparnya responden dengan media informasi tidak akan mempengaruhi kemungkinan seorang laki-laki melakukan pernikahan usia dini. Hal ini dapat dilihat dari jawaban responden saat pengisian kuesioner yang menunjukkan bahwa distribusi jawaban responden dengan yang kurang terpapar ataupun yang terpapar media informasi hampir sama sehingga tidak berhubungan dengan keputusan untuk melakukan pernikahan usia dini.

Penelitian ini tidak sejalan dengan teori Bungin (2001), semakin banyak media yang memuat gambar ke arah pornografi maka semakin kuat memberikan rangsangan kepada para pembaca dan semakin menikmati tayangantayangan pornografi yang disajikan bahkan cenderung berperilaku seksual. Hal ini juga sejalan dengan penelitian Raharjo (2013), yang mengatakan responden menggunakan media untuk melihat hal-hal negative memiliki risiko melakukan pernikahan dini 5,53 kali lebih besar dibandingkan dengan responden yang menggunakan media untuk melihat hal-hal positif.

Berdasarkan BKKBN (2017), paparan informasi seksualitas dari media massa baik cetak maupun elektronik cenderung bersifat pornografi dan pornoaksi sehingga dapat menjadi referensi yang tidak mendidik bagi remaja yang dapat menyebabkan remaja ingin tahu, ingin mencoba, akan meniru apa yang dilihat dan didengarnya dari media massa tersebut. Wuri (2007), menyatakan bahwa remaja semakin banyak mendapatkan materi pornografi dari media massa tentunya akan cenderung bersikap mendukung terhadap terjadinya hubungan 
seksual pranikah bahkan dapat mendorong terjadinya pernikahan dini.

Pratiwi (2017), menyatakan penggunaan handphone justru dapat memperlancar komunikasi dan pertemuan informan dengan pasangan ataupun orang yang baru dikenalnya melalui media sosial, sehingga pertemuan tersebut bisa mengarah kepada perbuatan yang tidak baik.

\section{KESIMPULAN}

Ada hubungan faktor pendidikan, status sosial ekonomi, pengaruh teman sebaya, dan peran orang tua dengan pernikahan usia dini di Kecamatan Semidang Alas Maras Kabupaten Seluma.

Tidak ada hubungan faktor pengetahuan, pekerjaan, dan keterpaparan media informasi dengan pernikahan usia dini di Kecamatan Semidang Alas Maras Kabupaten Seluma.

\section{SARAN}

Dinas kesehatan diharapkan untuk menjalin kerjasama dengan BKKBN untuk memberikan informasi beserta edukasi kepada remaja dan orang tua tentang dampak pernikahan usia dini. Peneliti selanjutnya diharapkan agar lebih mengkaji faktor-faktor yang berhubungan dengan pernikahan usia dini dengan variabel lain yang lebih spesifik, agar menghasilkan penelitian yang lebih baik lagi.

\section{DAFTAR PUSTAKA}

BKKBN, 2012. Survey Demografi dan Kesehatan Indonesia Tahun 2012. Jakarta; BKKBN.

BKKBN Prov Bengkulu, 2017. Tingginya Angka Menikah Dini BKKBN Gelar Workshop Genre yang diakses dari http://bengkulu.bkkbn.go.id/Lists/Berita/Dis pForm.aspx? ID $=1736 \&$ ContentTypeld $=0 \times 0$ 100A28EFCBF520B364387716414DEEC EB1E

BPS, 2013. Survey Sosial Ekonomi Nasional: Statistik Kesejahteraan Rakyat. Jakarta; BPS.

2017. Statistik Kesejahteraan Rakyat Provinsi Bengkulu, Bengkulu.
2018. Statistik Kesejahteraan Rakyat Provinsi Bengkulu, Bengkulu.

Bungin, B. (2001). Erotika Media Massa. Surakarta: Muhammadiyah Universiry Press.

Cahaya Perempuan WCC, 2017. Perempuan Menikah di Usia anak dan Usia Dini, Bengkulu.

Desiyanti, I.W. (2015). Faktor-Faktor Yang Berhubungan Terhadap Pernikahan Dini Pada Pasangan Usia Subur Di Kecamatan Mapanget Kota Manado. JIKMU, Vol. 5, No. 2, April 2015.

Dumilah, Retno. Fariji, Achmad. Petralina, Bintang. Pengaruh Teman Sebaya, Lingkungan Keluarga dan Budaya Terhadap Persepsi Remaja Tentang Perkawinan Di Bawah Umur. Jurnal IImiah Bidan, Vol. 4, No. 1 Tahun 2019.

Green, L,m W., et, al. 1980. Health Education Planning: Diagnostic Approach, Mayfield Publishing Company. California.

Karjono, Muhammad. M. 2014. Penyebab terjadinya Perkawinan dibawah Umur pada Remaja di Daerah Pesisir Pantai Kuta Kabupaten Lombok Tengah. Media Bina IImiah. Volume 8, No.7, Desember 2014: 34-37.

Khaparistia, Eka. Edward. 2015. Faktor-faktor Penyebab Terjadinya Pernikahan Usia Muda (Studi Kasus di Kelurahan Sawit Seberang Kecamatan Sawit Seberang Kabupaten Langkat). Jurnal IImu Kesejahteraan Sosial Vol. 14 No. 1 Juni 2015.

Kemenkes. 2010. Survei Kesehatan Nasional. Jakarta.

Kemenkes RI, 2013. Riset Kesehatan Dasar 2013. Jakarta, Badan Penelitian dan Pengembangan Kesehatan, Kementerian Kesehatan RI.

Muzaffak. 2013. Pengaruh Tingkat Pendidikan Dan Ekonomi Terhadap Pola Keputusan

52 Vol. 15, No. 1, April $2020: 1$ - 73 | 
Orang Tua Untuk Mengkawinkan Anaknya di Desa Karang Duwak Kecamatan Arosbaya Kabupaten Bengkalan. Paradigma. 2013;1(1):1-8.

Nursalim, faktor-faktor yang berhubungan dengan kejadian pernikahan dini pada remaja putri di Kecamatan Ma'rang Kabupaten Pangkep. Jurnal IImiah Kesehatan Diagnosis. Vol. 12, No. 5 Tahun 2018.

Pratiwi, B., dkk. Faktor-Faktor Yang Berhubungan Dengan Pernikahan Usia Dini di Kabupaten Bengkulu Tengah Tahun 2017. Laporan Akhir Penelitian BKKBN 2017.

Pratiwi, B., Angraini, W., Padila, P., Nopia Wati, N., \& Yandrizal, Y. (2019). Analisis Pernikahan Usia Dini di Kabupaten Bengkulu Tengah Tahun 2017. Jurnal Kesmas Asclepius, 1,(1), 14-24.

Priyanti, Maya Fitria. \& Erna Mutiara (2013). Faktor yang Berhubungan Dengan Perkawinan Usia Muda Pada Penduduk Kelompok Umur 12-19 tahun di Desa Puji Mulyo Kecamatan Sunggal Kabupaten Deli Serdang Tahun 2013. V0I.2, No.6.

Qibtiyah, Mariyatul. 2014. Faktor yang Mempengaruhi Perkawinan Muda Perempuan. Jurnal Biometrika dan kependudukan. Vol. 3, No. 1, Juli 2014.

Rafidah, at. Al. 2009. Faktor-faktor yang Berhubungan dengan Pernikahan Usia Dini di Kabupaten Purworejo Jawa Tengah. Berita Kedokteran Masyarakat.Vol. 25 No. 2, Juni 2009.

Rahardjo, Sumardi. Imron, Riyanti. 2013. Determinan Pernikahan Dini Di Kecamatan Kalianda. Jurnal Kesehatan, Vol. IV, No. 2, Oktober 2013. Hal. 357-363.

Rosmawar C. Faktor-faktor yang Berhubungan dengan Perkawinan di Usia Dini pada Wanita di Desa Ceurih Kupula Kecamatan Delima Kabupaten Pidie Tahun 2013. Stikes Ubudiyah Banda Aceh; 2013.

Soetjiningsih. (2006). Remaja Usia 1-18 Tahun Banyak Lakukan Perilaku Seksual Pranikah. Diakses 20 Agustus 2019.
Http://www.ugm.ac.id/id/post/page?id=165 $\underline{9}$.

Vasant C., llayaraja BS., dan Ramya S. 2015. Assessing Parents AwarenessOn Health Impacts of Early Marriage : A Study in Selected Villages of Moradabad, Uttar Pradesh. International Journal of Basic Medicine and Clinical Research, Vol 2, Isssue 5,2005.

Wuri. T. S. (2007). Analisis Faktor-Faktor yang Berhubungan dengan Sikap Siswa SMA Terhadap Hubungan Seksual (Intercourse) Pranikah di Kota Sukoharjo Tahun 2007. Semarang: Magister IImu Kesehatan Masyarakat Universitas Diponegoro.

Yunita, A. 2014. Faktor-faktor yang Berhubungan dengan Kejadian Pernikahan Usia Muda Pada Remaja Putri di Desa Pagarejo Kabupaten Wonosobo. Wonosobo; Artikel. 